\title{
A Profile of the Mortgage Crisis in a Low-and-Moderate-Income Community
}

\section{Lynn Fisher, Lauren Lambie-Hanson, and Paul S. Willen}

\begin{abstract}
:
This paper assesses the impact of the mortgage crisis on Chelsea, Massachusetts, a low-and moderate income community of 35,000 adjacent to Boston. After years of rapid growth, house prices started falling in 2005. According to our repeat-sales indices, by the end of 2009 prices had fallen by as much as 50 percent from their peak. Foreclosures have soared and lenders have repossessed or allowed short sales on more than 330 homes, resulting in a forced exit of at least one in 30 of the town's households. A large fraction of the foreclosed properties were twoor three-family homes, so the number of households affected by the crisis undoubtedly extends beyond the number of foreclosures. But there is some positive news. After a slow start, servicers appear to have become far more efficient at selling foreclosed properties, so the stock of real estate owned properties has been falling since 2008. For the most part, homeowners who bought prior to the peak of the boom have so far avoided selling in the moribund market and thus are poised to gain if and when the market recovers. In addition, the crisis has not prevented homeowners from maintaining and improving their properties: both the number and the dollar value of building permits have held up well even for those homeowners who have bought recently and likely have negative equity in their homes.
\end{abstract}

\section{JEL Classifications: R1, G01}

Lynn Fisher is an associate professor of real estate in the department of urban studies and planning and at the Center for Real Estate at the Massachusetts Institute of Technology. Her e-mail address is lfisher@mit.edu. Lauren Lambie-Hanson is a doctoral student in the department of urban studies and planning at the Massachusetts Institute of Technology and a graduate fellow in the research department at the Federal Reserve Bank of Boston. Her e-mail address is 1slh@mit.edu. Paul S. Willen is a senior economist and policy advisor at the Federal Reserve Bank of Boston. His e-mail is paul.willen@bos.frb.org

This paper, which may be revised, is available on the web site of the Federal Reserve Bank of Boston at http://www.bos.frb.org/economic/wp/index.htm. Originally prepared for the conference, "The American Mortgage System: Rethink, Recover, Rebuild," held in Philadelphia, PA on May 12-14, 2010, it will appear in the forthcoming book, Reinventing the American Mortgage System: Rethink, Recover, Rebuild, coedited by Susan M. Wachter and Marvin M. Smith, that will be published in Spring 2011. The authors thank Ken Stein and Joe Cooney, Directors of Assessing and Inspectional Services for the City of Chelsea, for providing data and our discussants, Kelly Edmiston and Ralph Bostic, two anonymous reviewers, Kris Gerardi, Chris Foote, and conference participants for helpful comments and suggestions.

The views expressed in this paper are those of the authors and do not necessarily represent those of the Federal Reserve Bank of Boston or the Federal Reserve System

This version: August 31, 2010 


\section{Introduction}

It is an accepted fact in the current policy debate that the U.S. housing crisis has damaged communities. A search for newspaper articles with the words "foreclosure" and "community" coupled with such words as "ravaged," "destroyed," and "damaged" turns up literally thousand of entries. In this paper, we make an attempt to measure the effects of the crisis in a systematic way.

We focus on Chelsea, Massachusetts, a city which is adjacent to and just north of Boston. We chose Chelsea partly because we have an exceptionally good dataset but also because Chelsea was particularly hard hit in the crisis. As we will show below, from the market's peak in 2005 to 2009, house prices fell by almost half and lenders foreclosed on or agreed to "short sales" on almost 8 percent of the one-to-three family properties in the city.

Chelsea is typical of poorer communities in New England, as 90 percent of its 34,356 residents live in census tracts identified by the Federal Financial Institutions Examination Council (FFIEC) as low-and-moderate income. Over 56 percent of its residents are Hispanic or Latino. As Calem, Gillen, and Wachter (2004) explain, communities like Chelsea, with high concentrations of low-income and minority residents, as well as borrowers with limited credit records, such as immigrants, became magnets for high-cost lending in the recent housing boom. Chelsea's land mass is small, about two square miles, making it one of the 50 most densely populated municipalities in the country.

According to 2008 census data, there are 12,798 housing units in Chelsea. Its housing stock is old, with almost two-thirds (8,158 units) built before 1940. Only 4,609 of those units are occupied by their owners. Chelsea's typical housing structure is the small multifamily building with more than half, or 6,579, of the units in two-to-four unit buildings.

What do we find in our study? There is good news and bad news to report.

As mentioned above, the bad news surrounds house prices and foreclosures. According to our repeat sales indices, by 2009 house prices had fallen by nearly 48 percent from their peak in 2005. These price estimates are not driven by foreclosures, as we exclude both foreclosure auctions and the sales of bank-owned properties from our sample. Excluding so-called short sales, where a lender agrees to take less than the outstanding balance, reduces the city's estimated price decline to about 40 percent from the 2005 peak. Such dramatic price falls, remarkably, are not unprecedented in Chelsea; in fact, through 2009 the descent in this current housing cycle has been significantly short of the price drop that occurred during the last cycle: between 1987 and 1993, Chelsea house prices fell by 57 percent.

Collapsing house prices in the current cycle have led to an explosion in foreclosure activity. Between 1998 and 2005, annual foreclosure numbers were in the single digits every year with two particular years, 2003 and 2004, registering no foreclosures at all. In 2005 foreclosures started to rise, and in 2008 there were 125 foreclosures or more than five times more than 
the 24 total foreclosures occurring in the eight-year period between 1998 and 2005. If we include short sales, the numbers are much higher. By our count, between 2006 and 2009 357 homeowners left their homes through either a foreclosure or short sale. According to the tax records, there are about 4,500 one-to-three family properties in Chelsea, meaning that roughly 8 percent of the city's homeowners have lost their homes since the mortgage crisis began. Maps of the city show that foreclosures were widespread, with at least one foreclosure on virtually every residential block in the city.

Even for homeowners not directly affected by foreclosure, falling prices have a deleterious effect. Depending on which price index we use, anyone who bought after either 2000 or 2002 owns a home that today is worth less than they paid. Taking inflation into account makes the situation even worse. Measured by the Core PCE deflator, the overall price level has increased by more than 20 percent since 2000. Since the typical homeowner is highly leveraged, falling prices have completely wiped out any downpayment investment for most homeowners who purchased since the beginning of the decade.

Of course, buyers benefit from lower prices. In the case of homes, repeat buyers are also sellers so the reduction in purchase prices is potentially offset by the reduction in the value of their current property. But for first-time home buyers, falling prices represent an opportunity to get into the housing market that was not present in 2005.

How has Chelsea dealt with falling house prices and foreclosures? Here the news is better - the picture is of a fundamentally viable community coping imperfectly with a bad situation. What would be worrisome is if the foreclosure crisis pushed Chelsea over the proverbial tipping point and transformed it into a dying community in which no one wanted to buy, stay, or invest. Yet there seems to be little evidence that any such dynamic is under way. We back up this claim with three points.

First, the stock of bank-owned property, known in the industry as "real estate owned" or REO, appears to be under control. One of the main avenues by which foreclosures purportedly damage communities is by generating vacancies as lenders evict homeowners but then have trouble selling the properties. In his study of REO inventories in metropolitan areas across the United States, Immergluck (2008) argues that there is a vicious cycle between increased REO stocks and declining property values, since lower prices diminish homeowners' equity, leading to more foreclosures, which further depress house prices. Vacancies may also directly affect the value of REO properties themselves. Coulton, Schramm, and Hirsch (2008) document the relationship between longer periods spent in REO status and lower resale prices. They argue that one force behind this relationship is the often prolonged time that REO properties spend vacant, when they are vulnerable to vandalism and theft of appliances, wiring, pipes, and even siding (12). During 2008 there was some initial evidence of growing REO stocks, when the ability of lenders to sell distressed properties did not keep 
pace with the rise in new foreclosures. But starting in 2009, two things happened. First, lenders rapidly increased their sales of distressed properties. Second, and more importantly, lenders made increasing use of short sales, meaning that properties were transferred from one bona fide homeowner to another and never entered the bank-owned portfolio.

Second, homeowners appear to be investing in their properties, despite the collapse in house price appreciation. One fear, as expressed by Haughwout, Peach, and Tracy (2009), among others, is that the collapse in house prices and the resulting number of homeowners with little or no equity would result in homeowners with little or no long-term interest in their properties. But Chelsea's building permit data tell a different story. After a dramatic fall in 2008 which may have been exacerbated by wider credit market problems, the city's permit activity had, by the beginning of 2009, returned to its 2005 level. In particular, among recent buyers there has been little fall-off in property investment, as those who bought after the housing market peaked in 2006 are among those most likely to have negative equity. Thus, contrary to some predictions, Chelsea's homeowners have lost equity but not an ongoing interest in their homes.

Third, long-term homeowners appear to remain committed to Chelsea. An exodus of homeowners would be one potential piece of evidence that residents consider Chelsea fatally wounded. In particular, we would expect such a trend to be concentrated among the homeowners who could most easily leave, the ones who still had positive equity in their homes despite recent price falls. In fact, we see the opposite effect. Owners with more than five years of tenure typically account for 75 percent of all sales in Chelsea, but in 2008 their share dropped to less than half. The exodus was of those owners who purchased at the market peak, not the city's long-term residents.

Our study is unapologetically narrow. We are neither comparing Chelsea with the rest of the country or elsewhere in Massachusetts nor are we suggesting that Chelsea is in any way unique. Our goal merely is to come up with some quantitative, absolute measures of what is happening in a hard-hit community during the current mortgage crisis. In the conclusion, we briefly discuss how to apply the lessons from Chelsea more broadly.

\section{Data}

Our data come from three sources.

(1) Public records

We use a dataset of property-level transactions assembled by the Warren Group, a Massachusetts-based company that specializes in collecting residential property records in New England 1 The dataset includes information on all one-to-three family and condo trans-

\footnotetext{
${ }^{1}$ For a discussion of the Warren data, see Foote, Gerardi, and Willen (2008).
} 
actions carried out since 1987, including mortgage originations, foreclosure petitions, foreclosure auctions, and deed transfers, both for foreclosure and non-foreclosure sales. Using the Warren data, we can observe when properties are sold through foreclosure, and we can distinguish properties that are sold at auction to a third party from those that become REO. We can also measure the time REO properties are held by banks before being resold. We also attempted to identify likely short sales, transactions in which the lender has agreed to allow the borrower to pay off a mortgage with the proceeds of a sale in which the price falls short of the loan's unpaid principal balance. The Massachusetts public records data do not identify short sales and, in fact, the discharge documents report that the lender "received full payment and satisfaction" of the loan. To get around this constraint, we constructed a rule using a matched sample of loans from the public records and from the First American CoreLogic LoanPerformance dataset of securitized subprime loans which, unlike the public records, reports investor losses on the disposition of a loan and thus allows us to identify short sales. The definition we developed for a short sale is a transaction in which the seller receives less than 75 percent of the total amount she borrowed to purchase the property. The matched sample shows low rates of false positives and false negatives using this rule.

The Warren data also include information on property traits, such as the structure's characteristics and assessed valuations. Because only property transactions that have occurred since 1987 are included in the dataset, we supplement it with information from the City of Chelsea Assessor's Office. We find that over 90 percent of all one-to-three family and condo properties in Chelsea are tracked by the Warren Group.

\section{(2) Mortgage Servicers}

The second dataset we use is a collection of records from large loan-servicing organizations that is maintained by LPS Applied Analytics, Inc 2 This dataset has fields for key variables set at the time of each loan's origination, including the amount borrowed, the value and location of the property that the secures the loan, whether the loan is classified as prime or subprime, and whether the loan is held in the lender's portfolio or has been packaged into a mortgage-backed security (MBS). We can also observe whether the loan is a first lien or a second lien and a host of interest-rate variables (such as whether the loan is fixed-rate or adjustable-rate and the manner in which the interest rate changes in the latter case).

\section{(3) Building Permits}

We also obtained records on every building permit filed with the City of Chelsea's Inspectional Services Department between January 1996 and July 2009 3 For each permit we know the property address, issue date, permit fee paid, and a description and cost estimate

\footnotetext{
${ }^{2}$ The dataset was originally created by a company called McDash Analytics; LPS acquired McDash in mid-2008. Among housing researchers, the dataset is still generally called the "McDash data." For more details, see Foote, Gerardi, Gotte and Willen (2009).

${ }^{3}$ For a full discussion of this dataset, see Fisher and Lambie-Hanson (2010).
} 
of the work to be completed. We cleaned and standardized the addresses, then matched the building permit records to the Warren Data for all one-to-three family dwellings. We excluded condominiums because it is often impossible to determine which condo units at a given address received the improvements. We believe that the building permit data in Chelsea are a good approximation of the improvements owners made to their properties, since the City patrols neighborhoods seven days a week, issuing "stop work" orders to those operating without permits.

\section{Prices}

Using sales data for 1987 to 2009, we calculated annual weighted repeat sales price indices following the methods developed in Case and Shiller (1987) and Case and Shiller (1989). Although Case-Shiller house price indices are typically calculated using only sales of singlefamily homes, we included single-family, two-family, three-family, and condominium properties for two reasons. First, single-family homes make up only 17 percent of properties in Chelsea. Ignoring other sales would not provide a clear picture of changes in the city's house prices. Second, without including other properties, our sample size would be too small to differentiate between signal and noise in price changes. We also constructed the indices separately by property type to assess the impact of this decision to combine different sized housing units, as well as to gain information on relative rates of price change.

We took care to focus, to the best of our ability, on "non distressed sales." We excluded all foreclosures, including those properties sold at foreclosure auction to third parties and those that became REO 4 We omitted sales through which properties left REO status, since lenders and servicers may sell properties at deep discounts to avoid managing them. We used our definition of short sales to calculate the price indices with and without these transactions, as some have argued that short sales also essentially represent distressed transactions. For the remaining transactions in our dataset, we omitted sales by owners who held their properties for less than seven days. To reduce the impact of outliers, we removed sales with prices less than $\$ 15,000$ or over $\$ 10$ million. We also excluded sales that generated log appreciation in excess of 10 .

However, the repeat sales methodology assumes no significant changes have been made to an individual property between each sale. If properties have been improved, the repeat sales index will overestimate house price appreciation. To address this problem, we used our information on investments in properties from building permit data and calculated the repeat sales indices again, controlling for the level of investment made between sales. We

\footnotetext{
${ }^{4}$ For a discussion of issues related to identification of REO properties in this dataset, see Campbell, Giglio, and Pathak (2009).
} 
included sales by owners of one-to-three family properties who purchased after 1996 and sold by July 2009. Because our building permit data span this period, we were able to measure the full amount of investment (with issued permits) made by these owners.

Finally, we examined price changes using a hedonic model, estimated separately for each property type. We included controls for the number of bedrooms and baths, living area, lot size, and age of the property. We estimated the set of equations a second time, including measures of the owners' investment made in the properties, as evidenced by building permits.

The top panel of figure1 1 shows that average prices in Chelsea more than doubled between 2000 and 2005, but fell sharply after 2006; in just two years (between 2007 and 2009), prices fell by about 40 percent. In contrast, prices across Massachusetts rose less dramatically between 2000 and 2005, and fell less than 13 percent between 2007 and 2009. The lower left panel of figure 1 shows that while all types of properties have been hard-hit in Chelsea, there has been less volatility in condo prices, partly because condos did not appreciate as rapidly in 2003-2005 as did single-family, two-family, and three-family properties.

These dramatic price changes were not exclusive to Chelsea. Other Massachusetts communities, including Lawrence, Lowell, Lynn, and New Bedford, were also hard-hit as Table1. shows. These four communities, like Chelsea, are made up of predominantly low-to moderate-

Table 1: House Prices in Chelsea and Elsewhere in Massachusetts

\begin{tabular}{llcccccc}
\hline \hline Year & Chelsea & Lawrence & Lowell & Lynn & New Bedford & MA \\
\hline Trough & Year & 1993 & 1995 & 1993 & 1994 & 1995 & 1992 \\
& Index (1987=100) & 46 & 46 & 57 & 60 & 80 & 84 \\
& \% Change & -54 & -54 & -43 & -40 & -20 & -16 \\
\hline Peak & Year & 2005 & 2006 & 2006 & 2005 & 2005 & 2006 \\
& Index (1987=100) & 223 & 243 & 205 & 240 & 245 & 250 \\
& \% Change & +385 & +431 & +257 & +304 & +207 & +199 \\
\hline Trough & Year & 2009 & 2008 & 2009 & 2009 & 2009 & 2009 \\
& Index (1987=100) & 133 & 131 & 151 & 153 & 181 & 215 \\
& \% Change & -40 & -46 & -26 & -36 & -26 & -14 \\
\hline \hline Source
\end{tabular}

Source: Authors' calculations.

income neighborhoods, as defined by the FFIEC. Like Chelsea, they also have older housing stock with more small multifamily properties, higher median home values, greater poverty rates, and more residents who are immigrants than is typical of most other Massachusetts towns.

One possible explanation for the large declines in house prices, as captured by the indices, is the inclusion of short sales. As previously mentioned, it is difficult to identify these transactions in our data. Short sales have also become more common in recent years, and that trend appears to put a downward bias on estimates of recent house prices. In 2008 and 2009, over 10 percent of all residential real estate transactions in Chelsea were likely short sales, as compared to a historic average of only 4 percent of transactions being short sales. Using the argument that these are distressed sales, like foreclosures, we exclude these 
transactions from the index calculations. The results, seen in the top panel of figure 1, show 2009 prices falling to 112 percent of 1987 levels, yet 2009 prices fell only to 133 percent of 1987 levels when short sales are excluded. The differences in the indices with and without the inclusion of short sales become greater each year since 2007, the same period over which short sales became increasingly common.

Another possible problem is that traditional indices may also overestimate changes in house prices by failing to account for the owners' investment in the properties. Adjusting the price index to account for such investments, we find that declines in prices from the 2005 market peak are only slightly overestimated by traditional indices. Recall that this version of the index, shown in the lower right panel of figure 1, includes only sales by owners who purchased after 1995 and sold before July 2009. Recalculating the index by controlling for investment and excluding short sales further reduces estimates of the recent decline in house prices, though the overall change in values remains large regardless of which method is used. The traditional index estimates a 50 percent decline in prices between 2005 and 2009:Q2, while the index controlling for investment and excluding short sales estimates a 45 percent decline. To verify our findings from the repeat sales indices, we also calculate a set of hedonic models using annual fixed effects and a series of property trait covariates to estimate price indices. We find similar patterns in price changes using this method.

\section{Foreclosures}

In this section, we assess the magnitude of Chelsea's foreclosure problem. We first discuss measurement issues and then turn to a discussion of what factors characterized the failed homeownerships. We conclude the section by quantifying the number of lender-owned properties in the community.

\subsection{Measuring the problem}

To measure the number of foreclosures in Chelsea, we use two sources. The first is the Warren Group data previously discussed in which we define a foreclosure as the recording of a foreclosure deed which, roughly, extinguishes any claim the mortgagee has to the property and allows the lender to sell the property to a new owner. The advantage of a public record dataset is that it is comprehensive as, at least in theory, it includes every transaction for all the residential properties in the state, and it also provides each property's exact location information in the form of a street address.

Another alternative to looking at foreclosure deeds is looking at foreclosure starts. In Massachusetts, lenders initiate foreclosure proceedings with a court-filed "Order of Notice" 
in which the lender attempts to find out whether the borrower is in military service and thus protected against some foreclosure activity. The problem with orders of notice is that most do not lead to foreclosure. In some cases the borrower self-cures and in other cases the process drags on so long that the lender needs to file a second or third order of notice before actual foreclosure proceedings begin. Finally, the data is problematic as at least some foreclosures appear to occur without a recorded order of notice.

We then look at the LPS data, which provide much more detailed data on the loan's history. Whereas the public record data accurately record only the final stage of the process, the foreclosure deed, LPS tells us the delinquency status of the loan every month, whether the lender has initiated foreclosure proceedings, and the final disposition of the property. The disadvantage of the LPS dataset is that it only covers the subset of servicers that have a contractual relationship with LPS. This explains why, for example, table 2 based on LPS data shows only 69 foreclosures in 2008 whereas figure 2 constructed with Warren data shows nearly twice as many foreclosures.

\subsection{Overall characterization}

The top panel of figure 2 shows foreclosure activity in Chelsea since the late 1980s. The current crisis is obviously visible with foreclosures rising in 2006 after a prolonged period of exceptionally low foreclosure activity. Foreclosure growth accelerated in 2008 and reached an all-time high of 125 foreclosures before falling in 2009. The reasons for this decline are unclear and may involve an increasingly complex legal environment or an unwillingness by servicers to accelerate the foreclosure process in light of the difficulties they faced managing and disposing of distressed properties.

The second line in the top panel of figure 2 shows the total number of distressed transactions, including both foreclosures and short sales. As mentioned above in section 2, short sales - in which the lender allows the borrower to sell the house for less than the balance on the mortgage - represent an alternative way to end a troubled homeownership, and figure 2 shows that by 2009 short sales were almost as likely to occur as foreclosures. While short sales are generally more attractive for a community because there is no period in which the lender owns the property and thus the property is less likely to be vacant, short sales still signal mortgage distress, ownership turnover, and potential house price instability in the community.

From 2006 to the end of 2009, lenders had foreclosed on 263 properties in Chelsea. According to the census, there are about 4,500 one-to-three family dwellings in the city, so this means that since the start of the crisis, lenders have foreclosed on roughly 6 percent of the homes in Chelsea. If we include short sales, the crisis has directly affected 8 percent of the homes, or roughly one in 12 properties in the city. According to the bottom panel 
of figure 2, the foreclosure problem does not appear to be concentrated in any one part of Chelsea. There are foreclosures on virtually every residential block in the city, with the exception in the southwest corner, which is largely composed of condominiums.

With the LPS data, we can get a richer portrait of the crisis's effects on individual borrowers, albeit with the limitation, as mentioned earlier, that it depicts an arbitrary subset of the homes in Chelsea. In particular, we can see that lenders initiated almost twice as many foreclosure proceedings (the 284 "Petitions" in the table below) than they have so far completed (the 161 "Deeds"), among the sample of 2,343 loans originated before 2009 and active between 2007 and 2009. Table 2 also illustrates the impact of the crisis

Table 2: Foreclosures in Chelsea, 2007-2010

\begin{tabular}{|c|c|c|c|c|c|c|c|c|}
\hline \multirow{3}{*}{ Year } & \multirow{2}{*}{\multicolumn{2}{|c|}{ Total }} & \multicolumn{6}{|c|}{ "Originated... } \\
\hline & & & $\begin{array}{r}\text { before } \\
\# \text { of loa }\end{array}$ & $\begin{array}{l}2007 \\
=1766\end{array}$ & $\begin{array}{r}\text { in } 2 \\
\# \text { of loa }\end{array}$ & $\begin{array}{l}07 \\
s=337\end{array}$ & $\begin{array}{r}\text { in } 2 \\
\text { \# of loa }\end{array}$ & $\begin{array}{l}08 \\
s=240\end{array}$ \\
\hline & Petitions & Deeds & Petitions & Deeds & Petitions & Deeds & Petitions & Deeds \\
\hline 2007 & 71 & 23 & 67 & 23 & 4 & 0 & - & - \\
\hline 2008 & 81 & 67 & 60 & 59 & 20 & 8 & 1 & 0 \\
\hline 2009 & 102 & 47 & 85 & 36 & 15 & 10 & 2 & 1 \\
\hline 2010 (Jan-Apr) & 30 & 24 & 18 & 20 & 10 & 3 & 2 & 1 \\
\hline Total & 284 & 101 & 230 & 133 & 49 & 21 & 5 & 2 \\
\hline lotal & 284 & 101 & $13 \%$ & $8 \%$ & $15 \%$ & $6 \%$ & $2.1 \%$ & $0.8 \%$ \\
\hline
\end{tabular}

Source: Authors' Calculations.

on households in Chelsea. Of borrowers with loans originated prior to 2007 and who were current at the end of 2006, more than 13 percent were the subject of a foreclosure petition and 8 percent lost their homes. Of those who borrowed in 2007, lenders initiated proceedings on an even higher fraction, 15 percent, but completed proceedings only on 6 percent.

The good news is that the 2008 vintage appears to be performing quite well. There are only a handful of serious problem loans, which cannot be attributed to the pool's youth, as the loans from the previous vintage were already in deep trouble at an equivalent point in the cycle. One major reason for this difference is simply that Chelsea's house prices have stabilized somewhat. Another factor is the dramatic improvement in borrowers' creditworthiness. The median borrower in 2006 had a FICO score of 691, but by 2008 the median score had risen to 724 . This is not to say that foreclosures have gone away in Chelsea. As of April 2010, there were 1,970 active first-lien mortgages in the LPS dataset. Of these, 98 were identified as "in foreclosure" (many post-petition, pre-deed) and another 152 were more than 90 days delinquent. 


\subsection{The REO problem}

During the mortgage crisis, the build-up of real estate owned (REO), or bank-owned, properties has been a major concern for policymakers. Many have expressed concerns that REO properties are magnets for thieves and vandals and their very presence on a street makes selling other properties more difficult, reduces prices and, in turn, generates more foreclosures. And indeed, figure 3 shows that the inventory of REO properties did climb dramatically after the foreclosure crisis started in 2006. The good news is that the stock of REO properties peaked in 2008 and then fell in 2009.

To better understand the evolution of the REO housing stock in Chelsea, it is useful to look at the flows into and out this category. Figure 3 shows that the net additions to REO properties fell in 2009, mostly because the rate at which lenders added to their stock of REO housing fell dramatically. In other words, despite the fact that flows out actually fell, the number of REO properties actually went down.

To understand why flows into the REO stock fell so much, we look at the disposition of what we call troubled properties, defined as ones for which the lender concluded in 2007, 2008, and 2009 that the borrower could not afford to service. As mentioned above, a lender can dispose of a troubled property by allowing a short sale or foreclosing. If the lender forecloses, it must hold an auction, where it can then choose whether to accept a bid or retain the property as REO in hopes of getting a better price. The LPS data summarized

Table 3: Disposition of Troubled Property in Chelsea, 2007-2009

\begin{tabular}{lccccc}
\hline \hline & Troubled & \multicolumn{2}{c}{ Foreclosure } & Short & \% Enter \\
& Properties & REO & Auction & Sale & REO \\
\hline 2007 & 49 & 41 & 3 & 5 & $84 \%$ \\
2008 & 161 & 120 & 5 & 36 & $75 \%$ \\
2009 & 121 & 61 & 10 & 50 & $50 \%$ \\
\hline \hline
\end{tabular}

Source: Authors' Calculations.

in table 3 indicate that between 2007 and 2009, the share of troubled properties that went into REO status fell from 84 percent to 50 percent. In turn, this decline resulted both from a greater willingness of lenders to sell at auction and to do short sales.

The ability of lenders to sell properties at auction and to allow short sales tells us more, in some ways, more about Chelsea than it does about the lenders. The simple fact that they can find buyers, even at depressed prices, means that at least some people believe that Chelsea remains a viable community. In some depressed U.S. communities, finding buyers willing to pay anything more than a token amount for distressed properties has been a challenge. See the discussion in Coulton, Mikelbank, and Schramm (2008). 
There is also cautiously hopeful news among the REO properties. Of those 181 properties that became REO in 2008 or 2009, 154 (85 percent) have been resold to third party buyers by 2010 Q2. Community stakeholders are typically concerned with the incidence of REO property flipping; however, we find that only ten of these 154 REO buyers (6 percent) resold their properties by the 2010 Q2. This is not to say there are no investors in Chelsea. Among the 2008 and 2009 foreclosures alone, we have identified four unique buyers who have purchased three or four REOs each. However, the concentration of REO purchases among the most active buyers in Chelsea is very small relative to a city like Cleveland, where the most active buyers have each purchased between two and six percent of all REOs sold (Coulton, Schramm, and Hirsch, 2008, p. 7).

\section{Investment}

In this section, we look at Chelsea's building permit data as a way to measure how willing owners were to invest in their properties during this period. Since it is forward-looking, owner investment is a particularly useful measure of attitudes toward the community's future, as owners who viewed the community as fatally wounded by the crisis would be unlikely to invest more money in their properties. Further, some have argued that homeowners with negative equity are not really homeowners at all and are less likely to invest.5 But Chelsea tells a different story.

The collapse of the real estate market that began in 2006 does appear to have reduced such owner investment substantially, but some recovery appears underway. The top two lines in figure 4 show the changes in the number and total dollar value of building permits for improving one-to-three family properties, respectively. Our quarterly backward-looking moving average of the number of permits falls by almost half, from a peak of 117 permits per quarter in 2006:Q2 to a trough of 65 permits in 2008:Q3. The dollar figures tell a similar story with permits for nearly $\$ 1.2$ million of work in 2006:Q3 dropping to $\$ 738,000$ in 2008:Q3. In the meantime, investment seems to have bounced back, with 92 permits issued in the 2009:Q2 collectively worth almost $\$ 900,000$.

Comparing 2006 and 2009 is somewhat misleading, however, because the 2005-2006 period is something of an anomaly. 2005:Q3 was the first time Chelsea building inspectors issued more than 100 permits in a single month. Thus, the number of permits in 2009:Q2 is low relative only to that exceptional boom period and actually exceeds the total issued for almost every quarter prior to 2006.

To add to the interpretive difficulty here, credit supply problems may account for some of the drop. First, the collapse in house prices and the concomitant reduction in home

\footnotetext{
${ }^{5}$ See Haughwout, Peach, and Tracy (2009), for example.
} 
equity made it difficult for homeowners to get second mortgages or do cash-out refinances, a traditional source of funding for home improvement. LPS reported 125 cash-out refinances in 2006 and only 24 in 2008. Second, many have argued that the financial market troubles of 2008, which culminated in the collapse of Lehman Brothers and AIG, created a credit crunch in which lenders were unwilling to lend to anyone, even if they did have a good business plan or reasonable collateral.

In light of the credit supply issues, which persisted into 2009, the recovery of investment in home improvements during the first half of 2009 is all the more surprising. Despite house prices falling back to their 2001 level, which would make cash-out refinances impossible for a large fraction of homeowners, Chelsea's homeowners were able to make home improvements at a pace roughly consistent with 2005 .

To assess the question of whether homeowners with little or no equity are investing in their properties, we can look at the investment activity of recent homebuyers. The third line in figure 4 shows the share of permits accounted for by homeowners who bought in the three

preceding years. For example, the 2007 figure shows investments by homeowners who bought in 2005, 2006 or 2007. In general, recent homebuyers account for a disproportionate share of building permits. Figure 4 shows that this share remained stable through this three-year period, which is remarkable given that in 2008 we are considering owners who bought in 2006, 2007, and 2008 and had seen their property's value collapse anywhere from 20 to 50 percent. There is no evidence in our data that we should view homeowners with negative equity as renters, at least not as far as investment in home improvements is concerned.

\section{Sales}

In analyzing Chelsea's housing market during in the mortgage crisis, we have focused thus far on prices and foreclosures, as these are the most salient pieces of evidence. However, the evolution of sales displays equally significant variation and also is important to understanding the crisis. In 2004 and 2005, about 45 homes, or about 1 percent of the properties in the city, according to 2009 assessor's records, changed hands each month and, with rising prices, almost none of these transactions were distressed sales. This represented a dramatic increase over earlier years as monthly sales rates were typically under 30 in 2002 and 2003. By 2007, the total number of sales was cut in half, and over one-quarter were distressed sales, including sales into foreclosure, sales out of REO, and likely short sales. Total sales increased in 2008 and 2009 to about 28 sales per month, still more than 40 percent below the 2005 peak, and a majority of these were distressed sales.

The first point to make here is that the reduction in sales volume casts doubt on the theory that foreclosures have driven down house prices by increasing the supply of residential 
real estate on the market. If the effect of foreclosures was to shift the supply curve to the right, we would see a drop in prices and an increase in the number of transactions. The drop in both prices and transactions suggests a reduction in demand, not an increase in supply.

But it is possible to go further and argue that the falling sales volume is actually a good sign for Chelsea and reflects the high value that owners place on their properties. Arguably, the entire supply of houses for sale in a market includes all properties, not just those currently listed for sale-the idea being that for a sufficiently high price, everyone would eventually sell. The bad news for Chelsea would be if we were to see an enormous number of people selling at low prices, but we find no evidence of that occurring.

The question of why people place high values on their homes, even in a depressed market, is more difficult to answer. One possibility is that they view the current fall in prices as transitory as, indeed, the much larger Massachusetts house price fall in the mid-1990s turned out to be. Such logic may have some merit, as the run-up in prices that preceded the 1990s downturn almost exactly parallels the run-up in this cycle.

It is instructive to look at the composition of sales as well. One natural explanation for the low sales volume is that owners suffer from psychological biases and are unwilling to accept that their properties are currently worth less than they paid, a phenomenon documented by Genesove and Mayer (2001). In fact, we see the opposite pattern in the Chelsea data. Long-term owners, the ones least likely to have witnessed a big price fall since purchase, are less likely to sell, as shown by the following table of sales. The fact that long-term owners

Table 4: Sales of Long-term Owners in Chelsea, 2004-2009

\begin{tabular}{lc|c}
\hline \hline & \multicolumn{2}{c}{$\begin{array}{c}\text { Sales by owners with more } \\
\text { than five years of tenure }\end{array}$} \\
\cline { 2 - 3 } Year & \# of sales & as \% of all sales \\
\hline 2004 & 390 & 72 \\
2005 & 398 & 76 \\
2006 & 254 & 67 \\
2007 & 173 & 70 \\
2008 & 126 & 48 \\
2009 & 151 & 59 \\
\hline \hline
\end{tabular}

Source: Authors' Calculations.

in Chelsea are not selling in the currently depressed housing market is potentially positive news along another dimension. One concern about a big fall in prices is that homeowners who had built big equity positions would be forced to sell in a down market. The fact that so few are selling suggests that the crisis has had muted equity-destroying effects for long-term owners and that they will be able to take advantage of a recovery if and when it occurs. 


\section{Conclusion}

The picture of Chelsea that we paint is of a community under enormous economic stress but displaying a fair amount of resilience. Chelsea's location means that, ultimately, its viability depends on that of its big next-door neighbor, Boston. So long as Boston is healthy, there will be demand for real estate in a nearby residential community. Fears that the foreclosure crisis would tip Chelsea into long-term decline do not seem well-founded. Its residents are not running for the exits and selling at any price, but rather appear committed and even willing to invest in their community.

But then location is the key issue when comparing Chelsea with other low-and-moderateincome communities in the region and in the nation. For similar cities in the industrial midwest, the collapse of manufacturing has raised questions about their long-term viability. It is likely that a similar analysis of a city adjacent to Cleveland or Detroit or even Springfield, Massachusetts would not paint such an optimistic scenario. 


\section{References}

Calem, Paul S., Kevin Gillen, and Susan Wachter. 2004. "The Neighborhood Distribution of Subprime Mortgage Lending." Journal of Real Estate Finance and Economics 29(4): 393-410.

Campbell, John Y., Stefano Giglio, and Parag Pathak. 2009. "Forced Sales and House Prices." Working Paper No. 14866. Cambridge, MA: National Bureau of Economic Research.

Case, Karl E., and Robert J. Shiller. 1987. "Prices of Single-Family Homes Since 1970: New Indexes for Four Cities." Working Paper No. 2393. Cambridge, MA: National Bureau of Economic Research.

Case, Karl E., and Robert J. Shiller. 1989. "The Efficiency of the Market for Single-Family Homes." American Economic Review 79(1): 125-137.

Coulton, Claudia, Kristen Mikelbank, and Michael Schramm. 2008. "Foreclosure and Beyond: A Report on Ownership and Housing Values Following Sheriff's Sales, Cleveland and Cuyohoga County, 2000-2007." Center on Urban Poverty and Community Development. Cleveland: Case Western Reserve University. Available at http://blog.case.edu/msass/2008/01/13/Foreclosure_and_Beyond_final.pdf.

Coulton, Claudia, Michael Schramm, and April Hirsch. 2008. "BEYOND REO: Property Transfers at Extremely Distressed Prices in Cuyahoga County, 2005-2008." Center on Urban Poverty and Community Development. Cleveland: Case Western Reserve University. Available at: http://blog.case.edu/msass/2008/12/09/20081209_beyond_reo_final.pdf.

Fisher, Lynn M., and Lauren Lambie-Hanson. 2010. "Tenure and Foreclosure: Indentifying Investor-Owners and Assessing Their Impact: A Case Study of Chelsea, MA." Boston, MA: Citizens Housing and Planning Association. Available at http://www . chapa.org/files/f_1266423752CHAPA_Feb15FisherandLambie-Hanson.pdf.

Foote, Christopher, Kristopher Gerardi, Lorenz Goette, and Paul S. Willen. 2010. "Reducing Foreclosures: No Easy Answers." In NBER Macroeconomics Annual Volume 24, ed. Daron Acemoglu, Kenneth Rogoff, and Michael Woodford, 89-138. Chicago: University of Chicago Press. 
Foote, Christopher L., Kristopher Gerardi, and Paul S. Willen. "Negative Equity and Foreclosure: Theory and Evidence." Journal of Urban Economics 64(2): 234-245.

Genesove, David, and Christopher Mayer. 2001. "Loss Aversion and Seller Behavior: Evidence from the Housing Market." Quarterly Journal of Economics 116(4): 1233-1260.

Haughwout, Andrew, Richard Peach, and Joseph Tracy. 2009. "The Homeownership Gap." Staff Report No. 418. New York: Federal Reserve Bank of New York. Available at http://www.newyorkfed.org/research/staff_reports/sr418.pdf.

Immergluck, Dan. 2008. "The Accumulation of Foreclosed Properties: Trajectories of Metropolitan REO Inventories during the 2007-2008 Mortgage Crisis." Community Affairs Discussion Paper No. 02-08. Atlanta: Federal Reserve Bank of Atlanta. Available at http://www.atl.frb.org/filelegacydocs/dp_0208.pdf. 

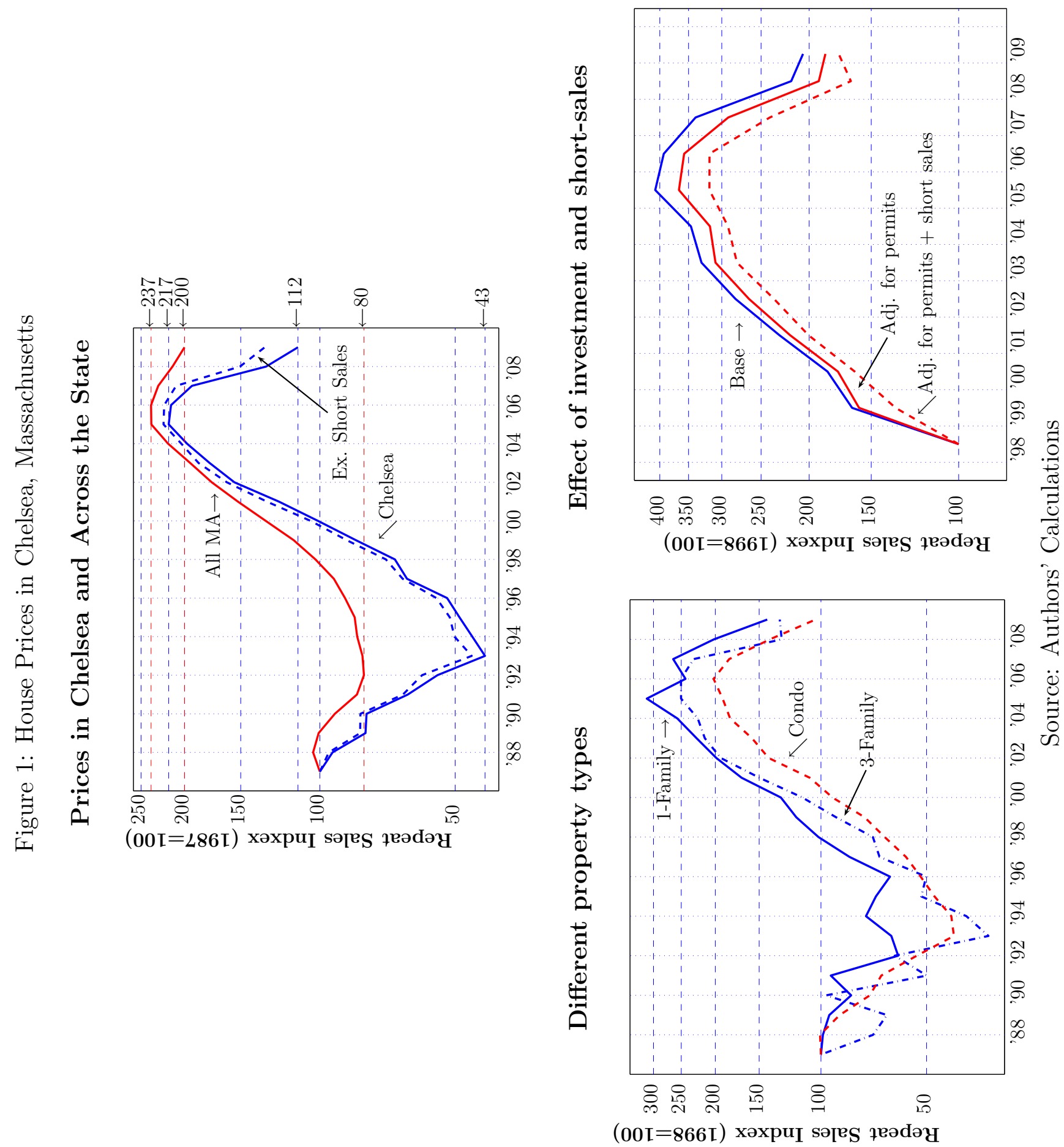
Figure 2: Foreclosures in Chelsea, Massachusetts

Foreclosures and Likely Short Sales, 1989-2009

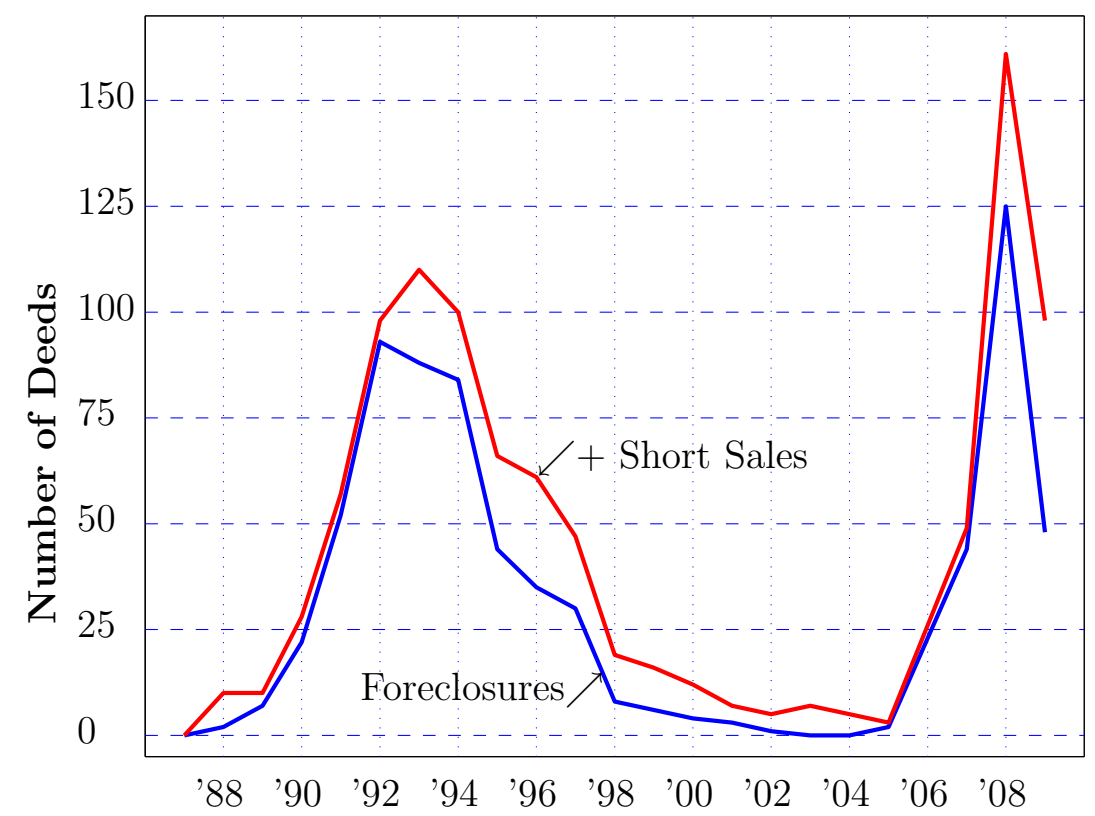

Map of Foreclosures

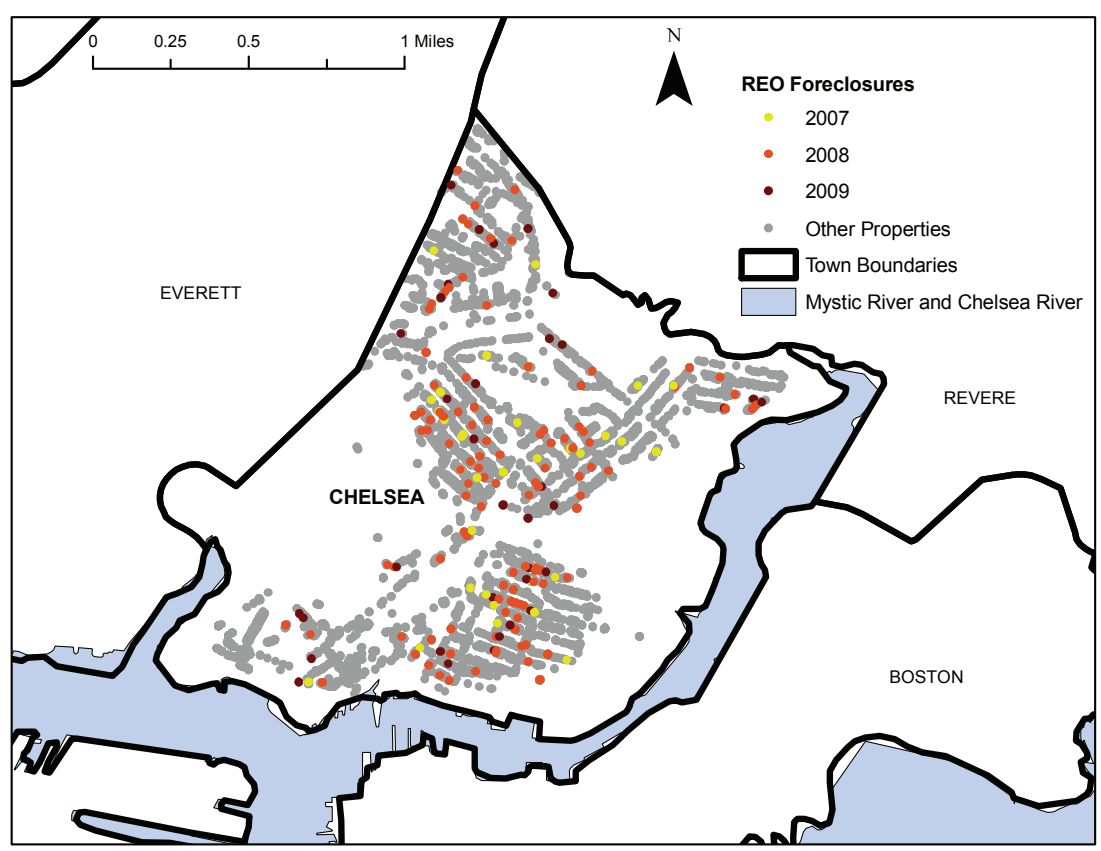

Source: Authors' Calculations 
Figure 3: Flows and Stock of REO Properties in Chelsea, Massachusetts, 1987-2009

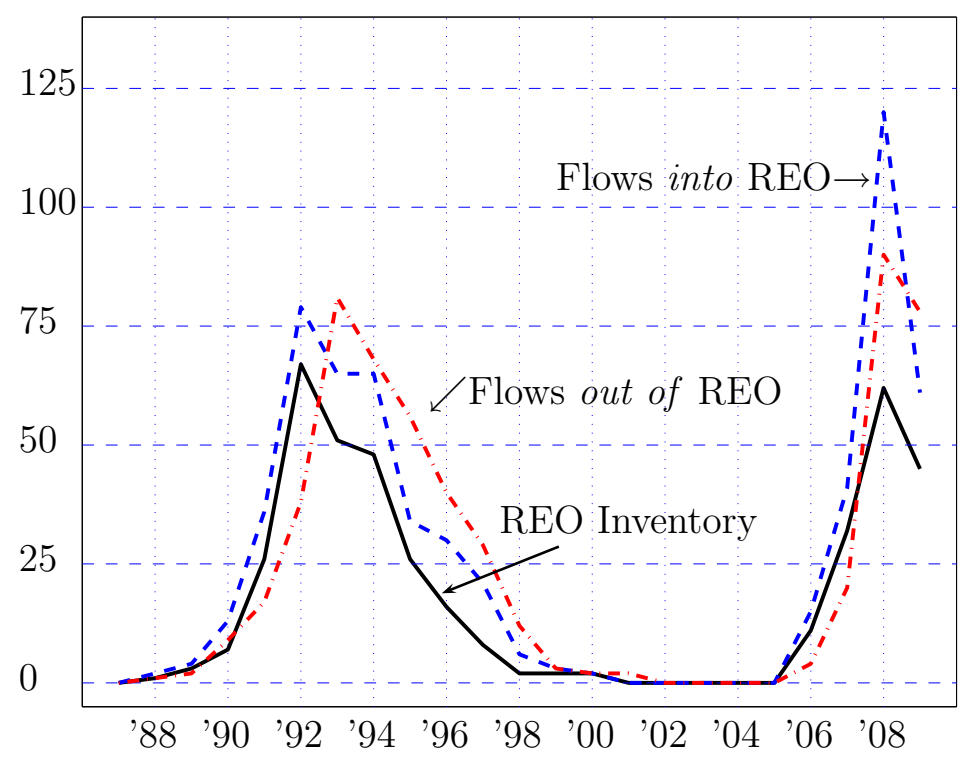

Figure 4: Permit Activity in Chelsea, Massachusetts, 1996-2009

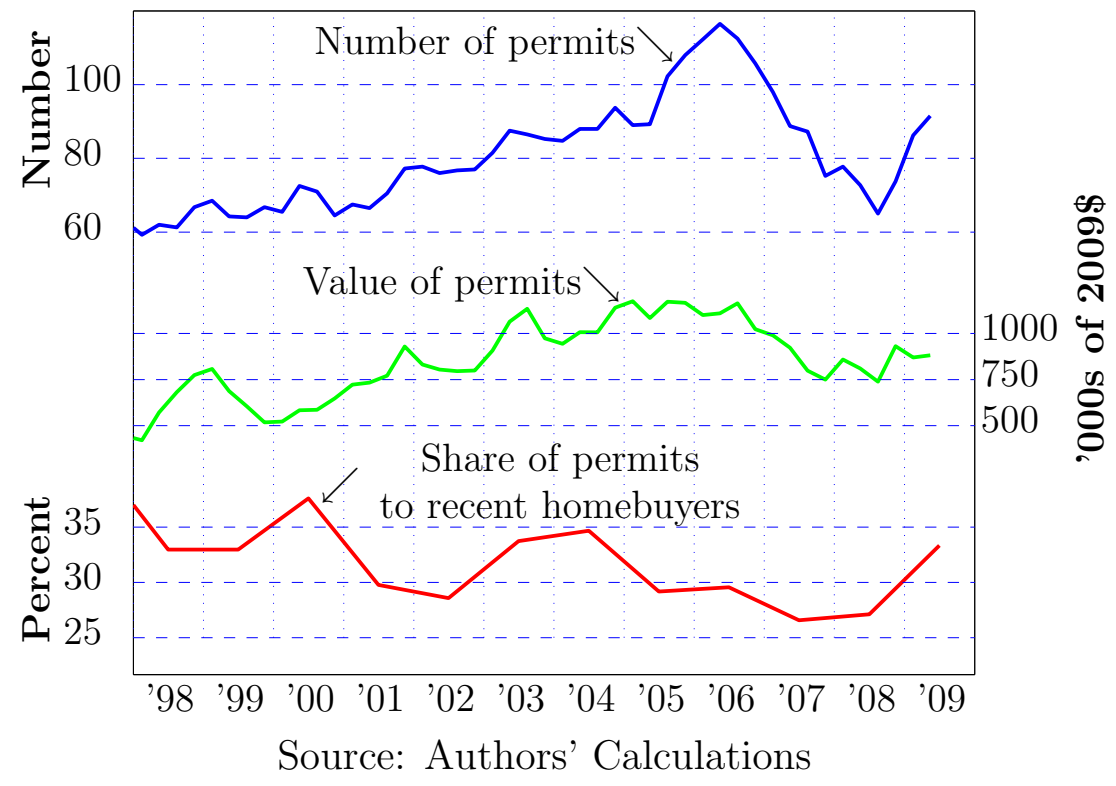

